\title{
Dental Anxiety in Relationship to Demographic Status and Periodontal Health in Adults
}

\author{
Dental Anksiyetenin Periodontal Sağlık ve Demografik Durum ile \\ ilişkisi \\ (1) Gülnihal Eren, (1) Oya Türkoğlu
}

Ege University Faculty of Dentistry, Department of Periodontology, İzmir, Turkey

Keywords

Dental anxiety, periodontal status, Modified Dental Anxiety scale

Anahtar Kelimeler

Dental anksiyete, periodontal durum, Modifiye Dental Anksiyete ölçeği

Received/Geliş Tarihi : 30.06 .2017

Accepted/Kabul Tarihi : 20.11.2017

doi:10.4274/meandros.70298

Address for Correspondence/Yazışma Adresi: Gülnihal Eren MD, Ege University Faculty of Dentistry, Department of Periodontology, İzmir, Turkey

Phone : +90 5368989434

E-mail : gulnihal_karasu@hotmail.com

ORCID ID: orcid.org/0000-0003-1148-2802

(C) Meandros Medical and Dental Journal, Published by Galenos Publishing House.

This is article distributed under the terms of the Creative Commons Attribution NonCommercial 4.0

International Licence (CC BY-NC 4.0).

\begin{abstract}
Objective: Dental anxiety is a major complication for many patients and practitioners. Dental fear often results in poor oral health in regard to poor cooperation. The aim of the present study was to determine the dental anxiety and its relation to socio-demographic status and periodontal health in adults.

Materials and Methods: In this cross-sectional study, a total of 187 patients were asked to complete a questionnaire consisted of the questions gathering information on sex, age, education level, income level, smoking habits and the last dental visit. The questionnaire also included Modified Dental Anxiety scale (MDAS) administered in Turkish language. The oral health status was determined with Community Periodontal index (CPI).

Results: Based on MDAS scores, 54\% of the subjects had mild anxiety, $41.7 \%$ had moderate anxiety, and $4.3 \%$ had severe anxiety. Anxiety was affected by age and gender $(p<0.05)$, but monthly income, education level, or smoking status had no effect on dental anxiety ( $p>0.05)$. Participants with higher CPI scores had significantly higher dental anxiety compared to those of lower CPI scores $(p<0.05)$. Conclusion: Encouragement of young individuals for regular dental visits since childhood would help to lower the dental anxiety. Frequent dental visits might prevent the negative dental experiences and contribute to decrease the dental fear.
\end{abstract}

Öz

Amaç: Diş hekimi korkusu nedeniyle hastaların gerekli diş tedavilerinden kaçınması ağız sağlığını olumsuz yönde etkiler. Bu çalışmanın amacı dental anksiyete ile sosyo-demografik durum ve periodontal sağlık arasındaki ilişkinin araştırılmasıdır. Gereç ve Yöntemler: Bu kesitsel çalışmaya dahil edilen 187 hastadan cinsiyet, yaş, eğitim düzeyi, gelir düzeyi, sigara içme alışkanlıkları ve son diş hekimi ziyareti ile ilgili ankete yanıt vermeleri istendi. Hastalara yöneltilen ankette Türkçe olarak düzenlenmiş Modifiye Dental Anksiyete ölçeği (MDAS) de yer aldı. Periodontal durum [Community Periodontal index (CPI)] ile belirlendi.

Bulgular: MDAS düzeylerine göre, olguların \%54'ünde hafif anksiyete, $\% 41,7$ 'sinde orta düzeyde anksiyete ve \%4,3'ünde ciddi anksiyete gözlendi. Anksiyetenin, yaş ve cinsiyete bağlı olarak değiştiği $(p<0,05)$, ancak aylık gelir, eğitim düzeyi veya sigara içme durumundan etkilenmediği belirlendi $(p>0,05)$. CPI skoru daha yüksek olan bireylerde MDAS düzeyleri, düşük CPI skoruna sahip bireylere kıyasla, anlamlı derecede yüksek bulundu $(\mathrm{p}<0,05)$. 
Sonuç: Çocukluk döneminden itibaren diş hekimi ziyaretleri için genç bireylerin teşvik edilmesi, dental anksiyeteyi azaltmaya yardımcı olacaktır. Sık diş hekimi ziyareti, olumsuz deneyimleri engelleyebilir ve diş hekimi korkusunu azaltmaya katkıda bulunabilir.

\section{Introduction}

Dental anxiety is a common problem for considerable number of patients and often results in inadequate oral health by less frequent dental visit, avoidance of dental treatment and poor cooperation (1-6). Several studies have evaluated the prevalence of dental anxiety range approximately 5\% to $30 \%$ depending on the population and measurement technique used $(4,6-8)$. Liu et al. (6) assessed dental anxiety among Chinese population and reported that $5 \%$ were suffering from dental phobia. In a Spanish population Rodriguez Vazquez et al. (8) assessed the stress before dental treatment and found that $10 \%$ patients scored high values stress. Thomson et al. (7) investigated New Zealand adults with a postal survey and observed that dental anxiety was reported by 20.8 per cent of respondents. In Turkish population, approximately $21 \%-24 \%$ of individuals experienced dental anxiety $(4,9,10)$. The etiology of dental anxiety is a multidimensional real or imaginative stimulus that leads to development of fear (11). It is likely to have been created by several factors such as general fearfulness, past traumatic experiences and negative information based on narratives offered by family or social environment $(12,13)$. People with high levels of dental anxiety might neglect their oral hygiene and have tendency to suspend dental treatment unless they suffer from severe pain. Eventually, dental anxiety becomes a veritable vicious circle that leads to worse oral health and may cause embarrassment associated with deterioration of social life (14). It has been reported that individuals with high dental anxiety more likely to have more missing teeth, more caries and worse oral hygiene in comparison to non-anxious individuals $(15,16)$. Self-reported questionnaires and anxiety rating scales place different degrees of emphasis on dental fear, which is expressed as changes in thoughts, physiological state and behavior by the population (17). These dental anxiety questionnaires show adequate levels of internal consistency (10). Modified Dental Anxiety scale (MDAS) is a quick and brief, 5 item questionnaire adapted from Corah's Dental Anxiety scale (DAS) (18) developed by Humphris et al. (19). An advantage of MDAS is that, it is cost effective instrument for population-based research. Also, MDAS was developed to improve validity of DAS by adding a question about administration of local anesthetic (1). MDAS has been found reliable and valid cross culturally and has been translated into different languages including Turkish (10). Individuals with periodontal disease are likely to report negative impacts in their oral health and express high general anxiety (20). Anxiety, depression and stress are not yet confirmed as definite risk factors of periodontal disease, but they are considered as potential factors affecting the occurrence, development and prognosis of periodontal disease $(21,22)$. Limited number of studies has been performed to investigate the relationship between dental anxiety and periodontal status in Turkey up to now $(4,23-25)$. As periodontal health status is an important factor affecting dental fear $(26,27)$ we hypothesized that greater indications of periodontal disease [i.e., higher Community Periodontal index (CPI) scores] were expected to be related to higher dental anxiety. Therefore, in the present study it is aimed to determine dental anxiety and its relation to demographic and periodontal status of patients who referred to Ege University Faculty of Dentistry.

\section{Materials and Methods}

\section{Patient's Recruitment}

This cross-sectional study was conducted among a sample of 187 patients attending Ege University Faculty of Dentistry, in the period spanning from September 2014 to March 2015. The purpose and procedures were fully explained to all participants prior to participation and written informed consent was obtained from all those wishing to participate in accordance with Helsinki Declaration. This study was reviewed and approved by the Ethical Committee of Ege University Faculty of Medicine (approval no: 15$9.1 / 13$ ). Inclusion criteria were age equal to or over 18 and agreement to participate in the study. Those who reported history or undergoing of psychological therapy, presented illiteracy and non-cooperation or took sedative agents 3 days before the survey were excluded from the study. 


\section{Data Collection and Questionnaires}

Initially, all patients were asked to fill a questionnaire. The questionnaire consisted of two sections. The first section contained questions gathering information on sex, age, education level, income levels, smoking habits and when they had last visit to the dentist. In the second section of the questionnaire, in order to assess dental anxiety, the patients were asked to complete MDAS administered in Turkish language (10). This scale includes 5 brief multiple-choice questions. And each question has a consistent answering scheme ranging from "not anxious" with a value of 1 and "extremely anxious" with a value of 5 . Also, periodontal status of the subjects was evaluated using CPI (28). The higher $\mathrm{CPI}$ scores refer the worsening periodontal status. One calibrated examiner (G.E.) was performed CPI measurements through examination. The intraexaminer reproducibility of the researcher for CPI measurements was evaluated with a manual periodontal probe, and the interclass correlation coefficient was $88 \%$.

\section{Statistical Analysis}

Differences between categorical variables were compared by using a chi-square or Fisher's exact test. Adjustment for gender has been performed for statistical analysis. The Shapiro-Wilk test was used to determine whether data were distributed normally. Data was not normally distributed, so group comparisons were performed by Mann-Whitney $\mathrm{U}$ test. Statistical analyses were performed using a statistical package (SPSS Inc., Ver. 20.0, Chicago, IL, USA). Differences were considered significant when $p$ value was $<0.05$.

\section{Results}

Demographic characteristics of the patients are presented in Table 1. The study population comprised 110 females and 77 males (mean age $38 \pm 13$ years, age range, 20 to 69 years). Mean anxiety level of the study subjects was $10.5 \pm 4.18$. Based on MDAS scores, $54 \%$ of the subjects were identified to have mild anxiety (5-10 total score), $41.7 \%$ were moderately anxious (11-18 total score), and $4.3 \%$ were suffering from high dental anxiety or dental phobia (19-25 total score). The results of the present study demonstrated that number of females who had moderate dental anxiety was significantly higher than males $(p=0.04)$.
Similarly, older subjects had significantly lower levels of dental anxiety than younger participants $(p<0.001)$. Dental anxiety was not affected by monthly income, education level $(p>0.05)$. The results also exhibited that dental anxiety was not related with smoking status of the study participants $(p>0.05)$. There was no significant difference in dental anxiety between participants with and without systemic disease $(p>0.05)$. Dental anxiety of participants who visited the dentist in last one year was not different from the other participants who did not visit the dentist ( $p>0.05)$. Participants with higher CPI scores had significantly higher dental anxiety compared to those of lower CPI scores ( $p=0.033$ ) (Table 1 ).

\section{Discussion}

This cross-sectional study evaluated the dental anxiety among patients who referred to Ege University Faculty of Dentistry for different dental treatment needs. Our results demonstrated that dental anxiety was related to gender, age and periodontal disease severity, but not with monthly income, education level, smoking and systemic disease status. Having a visit to a dentist in last one year was not found to be associated with dental anxiety. In the present study, the level of high dental anxiety was $4.3 \%$. Similar findings were found in a study by Prathima et al. (29) with $4.4 \%$, Moore et al. (30) with $4.2 \%$ and Locker et al. (31) with $4.4 \%$ high dental anxiety. However, Humphris et al. (32) found grater percentages of high dental anxiety with $11 \%$. In the present study subjects who referred to a dental school were included, in contrast Humphris et al. (32) used a structured interview on telephone in UK adults. It has been demonstrated that high dental anxiety level was the underlying cause for the avoidance of dental appointments (33). Therefore, selection of the study population from subjects attending dental clinics might be the reason for lower percentages of high dental anxiety as it was demonstrated in the present study. In the present study, the prevalence of dental anxiety was significantly higher in females than males, which was consistent with literature (17,30,34-36). Similarly, in Chinese population Liu et al. (6) stated that women were considered more anxious than men. The difference in dental anxiety between females and males might be possibly due to personality and psychological state, as women are being more likely 
to express their fears than men (37). In addition, a physiological research on human responses to pain stimuli has shown that women exhibit lower tolerance to pain than men (38). A significant negative correlation between age and dental anxiety has been repeatedly reported in community samples from developed countries $(19,32)$. Humphris et al. $(19,32)$ reported that younger subjects were more anxious than older ones among English population. In a cross-sectional study, Deogade and Suresan (39) found that younger patients were more anxious compared to their elder counterparts in Indian adult population. Also, Liddell and Locker (40) evaluated the relationship between age and dental anxiety in a Canadian population and stated that older adults reported less painful dental experiences than young adults. Similarly, Yildirim (4) found that young patients had significantly higher scores than others in a Turkish population. Our findings are in accordance with these studies $(4,19,32,40)$. In the present study, younger subjects had significantly higher dental anxiety than older participants. Post exposure to various diseases and treatments, increased ability to cope with negative experiences might be the explanations of not having high dental anxiety for older subjects. Also, high dental anxiety in younger participants could be due to the less experience of the dental instruments compared to older subjects. According to Fardal et al. (26) and Fardal and Hansen (27) periodontal status is an important factor affecting dental fear.

\begin{tabular}{|c|c|c|c|c|}
\hline & Anxiety score mild & Anxiety score moderate & Anxiety score high & $\mathbf{p}$ \\
\hline $\begin{array}{l}\text { Total } \mathrm{n}(\%) \\
\text { Gender }(\%) \\
\text { Female/male }\end{array}$ & $\begin{array}{l}101(54) \\
51 / 49\end{array}$ & $\begin{array}{l}78(42) \\
70 / 30\end{array}$ & $\begin{array}{l}8(4) \\
63 / 37\end{array}$ & 0.04 \\
\hline \begin{tabular}{|l|} 
Age (\%) \\
$20-29$ \\
$30-39$ \\
$40-49$ \\
$50-59$ \\
$60-69$ \\
\end{tabular} & $\begin{array}{l}44 \\
44 \\
48 \\
76 \\
92 \\
\end{array}$ & $\begin{array}{l}45 \\
50 \\
52 \\
21 \\
8 \\
\end{array}$ & $\begin{array}{l}11 \\
6 \\
0 \\
3 \\
0 \\
\end{array}$ & 0.001 \\
\hline $\begin{array}{l}\text { Monthly income (TL) (\%) } \\
<1000 \\
1000-2000 \\
>2000\end{array}$ & $\begin{array}{l}50 \\
58 \\
58\end{array}$ & $\begin{array}{l}47 \\
38 \\
33\end{array}$ & $\begin{array}{l}3 \\
4 \\
9\end{array}$ & 0.441 \\
\hline $\begin{array}{l}\text { Education level (\%) } \\
\text { Elementary school } \\
\text { Secondary school } \\
\text { University }\end{array}$ & $\begin{array}{l}54 \\
51 \\
57\end{array}$ & $\begin{array}{l}42 \\
45 \\
38\end{array}$ & $\begin{array}{l}4 \\
4 \\
5\end{array}$ & 0.989 \\
\hline $\begin{array}{l}\text { Smoking (\%) } \\
\text { Current } \\
\text { Non-smoker } \\
\text { Former smoker }\end{array}$ & $\begin{array}{l}44 \\
59 \\
59\end{array}$ & $\begin{array}{l}53 \\
37 \\
35\end{array}$ & $\begin{array}{l}3 \\
4 \\
6\end{array}$ & 0.357 \\
\hline $\begin{array}{l}\text { Systemic disease (\%) } \\
\text { Yes/no }\end{array}$ & $29 / 71$ & $35 / 65$ & $13 / 87$ & 0.368 \\
\hline $\begin{array}{l}\text { Last dental visit within one year (\%) } \\
\text { Yes/no }\end{array}$ & $43 / 57$ & $41 / 59$ & $25 / 75$ & 0.623 \\
\hline $\begin{array}{l}\text { CPI (\%) } \\
1 \\
2 \\
3 \\
4 \\
\text { Number of teeth }(\mathrm{n})\end{array}$ & $\begin{array}{l}14 \\
60 \\
21 \\
5 \\
23\end{array}$ & \begin{tabular}{|l}
9 \\
54 \\
28 \\
9 \\
24
\end{tabular} & $\begin{array}{l}0 \\
38 \\
25 \\
37 \\
26\end{array}$ & $\begin{array}{l}0.033 \\
0.157\end{array}$ \\
\hline
\end{tabular}


Stress, depression and anxiety are not yet confirmed as definite risk factors for periodontal disease but considered as potential risk factors in the concurrency and progression of periodontal disease $(20,21)$. Boyce et al. (41) suggested that fear and anxiety continue to be the main reason patients avoid or do not follow up with dental care. Individuals with high dental anxiety would postpone dental treatments and delayed treatment might lead to more painful interventions and this experience might exacerbate the person's level of dental fear, this situation described as "vicious cycle" (42). Dental fear appears to play an important role in this cycle, not only affecting the likelihood that people will delay going to the dentist, also modifying the association between dental avoidance and subsequent treatment need (43). Patients attending a dental faculty were selected in the present study. However, subjects with high dental anxiety may not ask for dental treatment unless they had to, and this situation might be the cause of lower percentages of high dental anxiety in the present study. Subjects with higher CPI scores showed significantly higher dental anxiety compared to those of lower CPI scores in the present study. Our results were in accordance with the studies by Yildirim (4) and Talo Yıldırım et al. (24) reported that periodontal status was better in patients those had low and moderate dental fear scores compared to patients that had high dental fear scores. On the other side, Sezer et al. (25) and Ay et al. (23) have found no statistically significant difference on dental anxiety levels related to periodontal status. Conflicting results among studies may be explained by the fact that periodontal disease severity of the patients was different among studies (4,23-25). Periodontal disease is usually painless and chronic; therefore patients do not become sufficiently aware and anxious before it reaches a certain level $(5,25)$. In order to determine whether periodontal disease severity really affect the level of dental anxiety, it is useful to conduct studies in different groups in terms of periodontal health status. A sample to fully represent the society may reveal different findings as it may involve individuals with both anxiety levels and different periodontal health levels. Our study has some limitations. Previous distressing experiences are often cited as the major factor in the development of dental anxiety $(43,44)$. In the present study, previous negative dental experiences have not been evaluated.
Further research including this topic is needed to clarify the role of previous dental experiences in the genesis of dental anxiety. The other limitation is the CPI index system. CPI index is based on a hierarchical concept of the progression of periodontitis, shows that a tooth with a score of 3 or 4 (a pocket present) should also have calculus present (score 2) and bleeding (score 1) (45-47). Also, it does not measure tooth mobility or attachment loss or furcation involvement $(48,49)$. Additionally, full mouth assessments including existent/filled/decayed teeth of the patient provide more precise information about oral health (50). Therefore, further studies including whole oral assessment would help to evaluate the relationship between oral health and dental anxiety. Lastly, the present cross-sectional study has been conducted on a limited population who referred to a dental school in İzmir. The cross-sectional design might be insufficient to demonstrate whether dental anxiety worsens periodontal health or presence of periodontal disease causes dental anxiety. Also, subjects with high dental anxiety would not ask for dental treatment unless they had to, and this situation might have affected the number of subjects with dental phobia in the present study. Therefore, multicenter studies with larger populations are needed to reveal the prevalence and severity of dental anxiety in Turkish population.

\section{Conclusion}

The present study indicates that females and young people have higher dental anxiety than males and older people. Since younger people had higher dental anxiety, encouragement of these people for regular and more often dental visits would help to lower the dental anxiety. Also, within the limits of this study the results showed that severity of periodontal disease might be the result of dental anxiety and vice versa. In order to determine whether periodontal disease severity really affect the level of dental anxiety, it is useful to conduct studies in different groups in terms of periodontal health status.

\section{Ethics}

Ethics Committee Approval: Ethical Committee of Ege University Faculty of Medicine (approval no: 159.1/13).

Informed Consent: Written informed consent was obtained from all those wishing to participate in 
accordance with Helsinki Declaration.

Peer-review: Externally peer-reviewed.

\section{Authorship Contributions}

Surgical and Medical Practices: G.E., Concept: G.E., Design: G.E., Data Collection or Processing: G.E., O.T., Analysis or Interpretation: O.T., Literature Search: O.T., Writing: G.E., O.T.

Conflict of Interest: No conflict of interest was declared by the authors.

Financial Disclosure: The authors declared that this study received no financial support.

\section{References}

1. Newton JT, Buck DJ. Anxiety and pain measures in dentistry: a guide to their quality and application. J Am Dent Assoc 2000; 131: 1449-57.

2. Erten H, Akarslan ZZ, Bodrumlu E. Dental fear and anxiety levels of patients attending a dental clinic. Quintessence Int 2006; 37: 304-10.

3. Boman UW, Lundgren J, Berggren U, Carlsson SG. Psychosocial and dental factors in the maintenance of severe dental fear. Swed Dent J 2010; 34: 121-7.

4. Yildirim TT. Evaluating the Relationship of Dental Fear with Dental Health Status and Awareness. J Clin Diagn Res 2016; 10: 105-9.

5. Wright CD, McNeil DW, Edwards CB, Crout RJ, Neiswanger K, Shaffer JR, et al. Periodontal Status and Quality of Life: Impact of Fear of Pain and Dental Fear. Pain Res Manag 2017; 2017: 5491923.

6. Liu Y, Huang X, Yan Y, Lin H, Zhang J, Xuan D. Dental fear and its possible relationship with periodontal status in Chinese adults: a preliminary study. BMC Oral Health 2015; 15: 18.

7. Thomson WM, Dixon GS, Kruger E. The West Coast Study. II: Dental anxiety and satisfaction with dental services. N Z Dent J 1999; 95: 44-8.

8. Rodriguez Vazquez LM, Rubinos Lopez E, Varela Centelles A, Blanco Otero Al, Varela Otero F, Varela Centelles P. Stress amongst primary dental care patients. Med Oral Patol Oral Cir Bucal 2008; 13: 253-6.

9. Firat $D$, Tunc EP, Sar V. Dental anxiety among adults in Turkey. J Contemp Dent Pract 2006; 7: 75-82.

10. Tunc EP, Firat D, Onur OD, Sar V. Reliability and validity of the Modified Dental Anxiety Scale (MDAS) in a Turkish population. Community Dent Oral Epidemiol 2005; 33: 357-62.

11. Neverlien PO, Backer Johnsen T. Optimism-pessimism dimension and dental anxiety in children aged 10-12 years. Community Dent Oral Epidemiol 1991; 19: 342-6.

12. Edmunds R, Buchanan $H$. Cognitive vulnerability and the aetiology and maintenance of dental anxiety. Community Dent Oral Epidemiol 2012; 40: 17-25.

13. Carter AE, Carter G, Boschen M, AlShwaimi E, George R. Pathways of fear and anxiety in dentistry: A review. World J Clin Cases 2014; 2: 642-53.

14. Moore R, Brodsgaard I, Rosenberg N. The contribution of embarrassment to phobic dental anxiety: a qualitative research study. BMC Psychiatry 2004; 4: 10.

15. Esa R, Savithri V, Humphris G, Freeman R. The relationship between dental anxiety and dental decay experience in antenatal mothers. Eur J Oral Sci 2010; 118: 59-65.

16. Locker D, Poulton R, Thomson WM. Psychological disorders and dental anxiety in a young adult population. Community Dent Oral Epidemiol 2001; 29: 456-63.

17. Aartman IH. Reliability and validity of the short version of the Dental Anxiety Inventory. Community Dent Oral Epidemiol 1998; 26: 350-4.

18. Corah NL. Development of a dental anxiety scale. J Dent Res 1969; 48: 596.

19. Humphris GM, Morrison T, Lindsay SJ. The Modified Dental Anxiety Scale: validation and United Kingdom norms. Community Dent Health 1995; 12: 143-50.

20. Warren KR, Postolache TT, Groer ME, Pinjari O, Kelly DL, Reynolds MA. Role of chronic stress and depression in periodontal diseases. Periodontol 2000 2014; 64: 127-38.

21. Vettore MV, Leao AT, Monteiro Da Silva AM, Quintanilha RS, Lamarca GA. The relationship of stress and anxiety with chronic periodontitis. J Clin Periodontol 2003; 30: 394-402.

22. Ng SK, Leung WK. Oral health-related quality of life and periodontal status. Community Dent Oral Epidemiol 2006; 34: 114-22.

23. Ay ZY, Çaglar F, Orun B, Uskun E. Hataların ağız sağ|ığı, dental anksiyete düzeyleri ve olası belirleyicileri ile ilgili bildirimlerinin ölçek sonuçlarıyla tutarlılığı. SDÜ Sağlık Bilimleri Dergisi 2014; 5: 56-61.

24. Talo Yıldırım T, Acun Kaya F, Uysal E. Evaluating the relations of dental fear with sex, age, marital status, frequency of dental visits, education levels, socio-economic and periodontal status. Turkiye Klinikleri J Dental Sci 2013; 19: 77-85.

25. Sezer U, Üstün K, Şenyurt SZ, Çiftci ME, Erciyas K. The evaluation of anxiety in periodontal patients. Cumhuriyet Dent J 2012; 15: 297-306.

26. Fardal O, Johannessen AC, Linden GJ. Pre-treatment conceptions of periodontal disease and treatment in periodontal referrals. J Clin Periodontol 2001; 28: 790-5.

27. Fardal $\mathrm{O}$, Hansen BF. Interviewing self-reported highly anxious patients during periodontal treatment. J Periodontol 2007; 78: 1037-42.

28. Ainamo J, Barmes D, Beagrie G, Cutress T, Martin J, SardoInfirri J. Development of the World Health Organization (WHO) community periodontal index of treatment needs (CPITN). Int Dent J 1982; 32: 281-91.

29. Prathima V, Anjum MS, Reddy PP, Jayakumar A, Mounica M. Assessment of anxiety related to dental treatments among patients attending dental clinics and hospitals in Ranga Reddy District, Andhra Pradesh, India. Oral Health Prev Dent 2014; 12: 357-64.

30. Moore R, Birn H, Kirkegaard E, Brodsgaard I, Scheutz F. Prevalence and characteristics of dental anxiety in Danish adults. Community Dent Oral Epidemiol 1993; 21: 292-6.

31. Locker D, Liddell A, Burman D. Dental fear and anxiety in an 
older adult population. Community Dent Oral Epidemiol 1991; 19: $120-4$.

32. Humphris GM, Dyer TA, Robinson PG. The modified dental anxiety scale: UK general public population norms in 2008 with further psychometrics and effects of age. BMC Oral Health 2009; 9: 20.

33. Pohjola V, Lahti S, Vehkalahti MM, Tolvanen $M$, Hausen $H$. Association between dental fear and dental attendance among adults in Finland. Acta Odontol Scand 2007; 65: 224-30.

34. Bergdahl M, Bergdahl J. Temperament and character personality dimensions in patients with dental anxiety. Eur J Oral Sci 2003; 111: 93-8.

35. Abrahamsson KH, Berggren U, Hakeberg M, Carlsson SG. The importance of dental beliefs for the outcome of dental-fear treatment. Eur J Oral Sci 2003; 111: 99-105.

36. Locker D. Psychosocial consequences of dental fear and anxiety. Community Dent Oral Epidemiol 2003; 31: 144-51.

37. Acharya S. Factors affecting dental anxiety and beliefs in an Indian population. J Oral Rehabil 2008; 35: 259-67.

38. Law SA, Britten N. Factors that influence the patient centredness of a consultation. Br J Gen Pract 1995; 45: 520-4.

39. Deogade SC, Suresan V. Psychometric assessment of anxiety with the Modified Dental Anxiety Scale among central Indian adults seeking oral health care to a dental school. Ind Psychiatry J 2016; 25: 202-9.

40. Liddell A, Locker D. Gender and age differences in attitudes to dental pain and dental control. Community Dent Oral Epidemiol 1997; 25: 314-8.

41. Boyce RA, Kirpalani T, Mohan N. Updates of Topical and Local Anesthesia Agents. Dent Clin North Am 2016; 60: 445-71.

42. Armfield JM, Stewart JF, Spencer AJ. The vicious cycle of dental fear: exploring the interplay between oral health, service utilization and dental fear. BMC Oral Health 2007; 7: 1.

43. Armfield JM. What goes around comes around: revisiting the hypothesized vicious cycle of dental fear and avoidance. Community Dent Oral Epidemiol 2013; 41: 279-87.

44. Skaret E, Raadal M, Berg E, Kvale G. Dental anxiety among 18-yrolds in Norway. Prevalence and related factors. Eur J Oral Sci 1998; 106: 835-43.

45. Benigeri M, Brodeur JM, Payette M, Charbonneau A, Ismail Al. Community periodontal index of treatment needs and prevalence of periodontal conditions. J Clin Periodontol 2000; 27: 308-12.

46. Lewis JM, Morgan MV, Wright FA. The validity of the CPITN scoring and presentation method for measuring periodontal conditions. J Clin Periodontol 1994; 21: 1-6.

47. Grytten J, Mubarak A. [CPITN (Community Periodontal Index of Treatment Needs)--what is its use and what does it mean?]. Nor Tannlaegeforen Tid 1989; 99: 338-43.

48. Cutress TW, Ainamo J, Sardo-Infirri J. The community periodontal index of treatment needs (CPITN) procedure for population groups and individuals. Int Dent J 1987; 37: 222-33.

49. Baelum V, Fejerskov O, Manji F. Periodontal diseases in adult Kenyans. J Clin Periodontol 1988; 15: 445-52.

50. Savage A, Eaton KA, Moles DR, Needleman I. A systematic review of definitions of periodontitis and methods that have been used to identify this disease. J Clin Periodontol 2009; 36: 458-67. 